\title{
Quality Features Analysis of an Assortment of Winter Wheat Genotypes Tested at A.R.D.S. Turda, in The Year of 2014
}

\author{
Camelia CAZACU (URDĂ) $)^{1,2 *}$, Rozalia KADAR ${ }^{2}$, Marcel M. DUDA ${ }^{1}$ \\ ${ }^{1}$ University of Agricultural Sciences and Veterinary Medicine Cluj-Napoca, Romania \\ *Corresponding author: cami1586@yahoo.com \\ Bulletin USAMV series Agriculture 72(2)/2015 \\ Print ISSN 1843-5246; Electronic ISSN 1843-5386 \\ DOI 10.15835/buasvmcn-agr: 11740
}

\begin{abstract}
Worldwide, the breeder efforts are focused in creating new winter wheat varieties with high quality parameters, according to the demands of the bakery industry. The natural conditions in Transylvania are very diverse. High-quality wheat varieties are required, therefore the aim is to detect and to create well-adapted winter wheat varieties to these local area conditions for obtaining high production and high quality features for this crop. To become aware of the valuable genotypes grown in the central and northern area of the country were studied quality characters from an assortment of the most common winter wheat varieties, tested at A.R.D.S. Turda, in the year of 2014.
\end{abstract}

Keywords: winter wheat, quality analysis, Turda area, production.

\section{INTRODUCTION}

Creating winter wheat genotypes that comply the requirements of the bakery industry in terms of its quality, it is one of the objectives for worldwide breeders. Over time, there have been made many studies on the variability in the protein content of wheat in fertilizer-free culture conditions and different levels of fertilizer (VOGEL et al., 1973; HRUSKOVA et al., 2000; HUSSAIN et al., 2006; MARQUE et al. 2004). Considering that not only fertilization influence the accumulation of grain protein and in consideration of climate change, the paper studies the protein content for 100 winter wheat genotypes under stress caused by chemical desiccation. Also wet gluten content and ash content were studied in this paper for 100 chemical desiccated winter wheat genotypes. The most important are gliadin and glutenin proteins that form gluten in the presence of water. It gives bread dough main characteristics of (http://www. rompan.ro/grau/). In terms of ash content of flours can be achieved classification according to quality classes.

\section{MATERIAL AND METHODS}

Experience was placed in the experimental field of cereals breeding laboratory in Turda, in the year 2014.

Quality indices were studied for 100 winter wheat genotypes at S.C.D.A. Turda in the year 2014. In the autumn of 2013, each genotype was sown by hand on $4 \mathrm{~m}$ rows, at $25 \mathrm{~cm}$ distance between plants in the row, resulting in a harvested area $1 \mathrm{~m}^{2}$. To identify the influence of drought on these quality indicators, 2 weeks after flowering, genotypes were treated with $\mathrm{NaClO}_{3}(2 \%)$ in order to induce drought artificially. This method of chemical desiccation was proposed by Blum (1988) and used by Cereal Research Non- profit company Szeged (2002) to determine drought 
resistance of some winter wheat genotypes. Quality parameters were studied for the genotypes cultivated in normal conditions and also for the chemical desiccated genotypes.

The flour for establishing quality indicators was achieved by grinding wheat samples with laboratory mill SJ 500. Using NIR analyzer from the company Dickey-John Instalab 600 were determined:

- protein content;

- wet gluten content;

- ash content.

To identify the genotypes with high production potential, production was calculated for winter wheat genotypes studied.

Climatic conditions in the year 2013-2014 were favorable for winter wheat crop (Fig. 1, Fig.
2). The genotypes studied had the right conditions to express at the level of production potential. Because of the rains in April, winter wheat plants had a luxuriant growth, the blooming was achieved with 9-14 days earlier than normal.

\section{RESULTS AND DISCUSSIOS}

Table 1 presents the variability parameters for protein content obtained at 100 winter wheat genotypes studied in the year 2014, at A.R.D.S. Turda. The average of protein content for the genotypes grown in normal coditions $(8.57 \%)$ was lower than protein content recorded for genotypes under chemical stress (10.42\%).

In the case of genotypes untreated with $\mathrm{NaClO}_{3}$ the range of variation for protein content

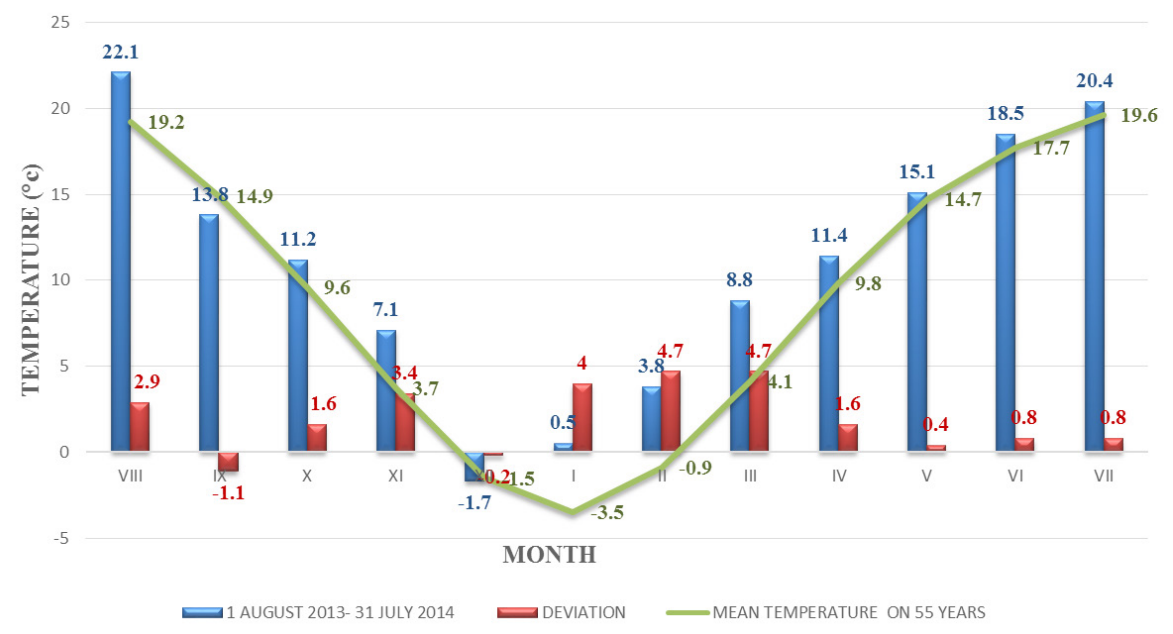

Fig. 1. Temperatures between $1^{\text {st }}$ of August 2013 and $3^{\text {st }}$ July 2014 at Turda $\left({ }^{\circ} \mathrm{C}\right)$

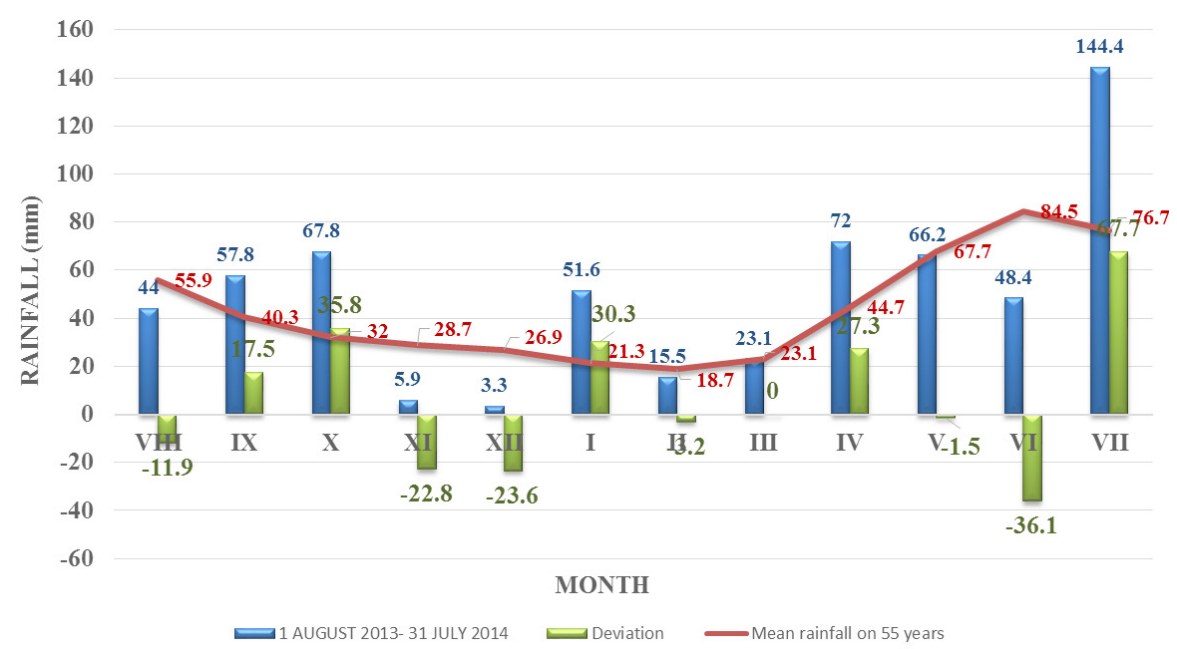

Fig. 2. Rainfall between $1^{\text {st }}$ of August 2013 and $31^{\text {st }}$ July 2014 at Turda (mm) 
was $5 \%$ with limits between 6.4 and $11.4 \%$. The small standard deviation value $(0.82)$ indicated that the experimental results had values around their average. The coefficient of variation $(\mathrm{s} \%)$ claculated denote a reduced variability of statistical repartition.

The protein content for chemical desicated genotypes was between 8.4 and $13.7 \%$ with a range of variation of $5.3 \%$. For these ones, standard deviation shows that the protein content, in most analyzed genotypes, has values close to the average. The coefficient of variation indicated a medium variability of statistical repartition.

These results confirm that dry climates favor the accumulation of protein in winter wheat grain.
The distribution of winter wheat genotypes studied for protein content (Fig. 3) shows that in dry conditions, 61 of the analyzed genotypes have a higher protein content of $10 \%$ while in normal condition, only 3 genotypes recorded values for protein content higher than 10\%. Among the 10 genotypes with the highest protein content (Table 2) are found varieties but also perspective lines of winter wheat genotypes. Apullum and Aniversar varieties had a protein content higher than $10 \%$ in normal conditions and over $12 \%$ in dry conditions. We also recomand for breeding programs in terms of protein content to use as genitors varieties like Capo, Rovine, GK. Kalasz, Bezostaia but also lines like: T.265-01, T.126-

Tab. 1. Protein content parameters variability for 100 winter wheat genotypes studied at A.R.D.S. Turda in the year 2014

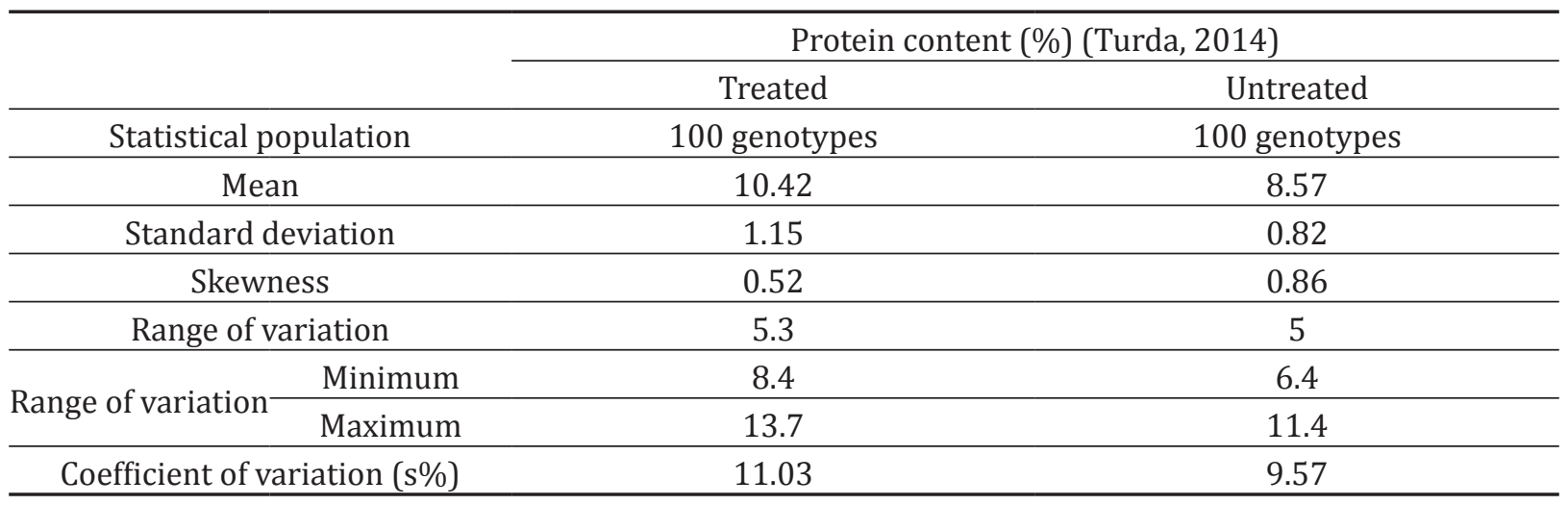

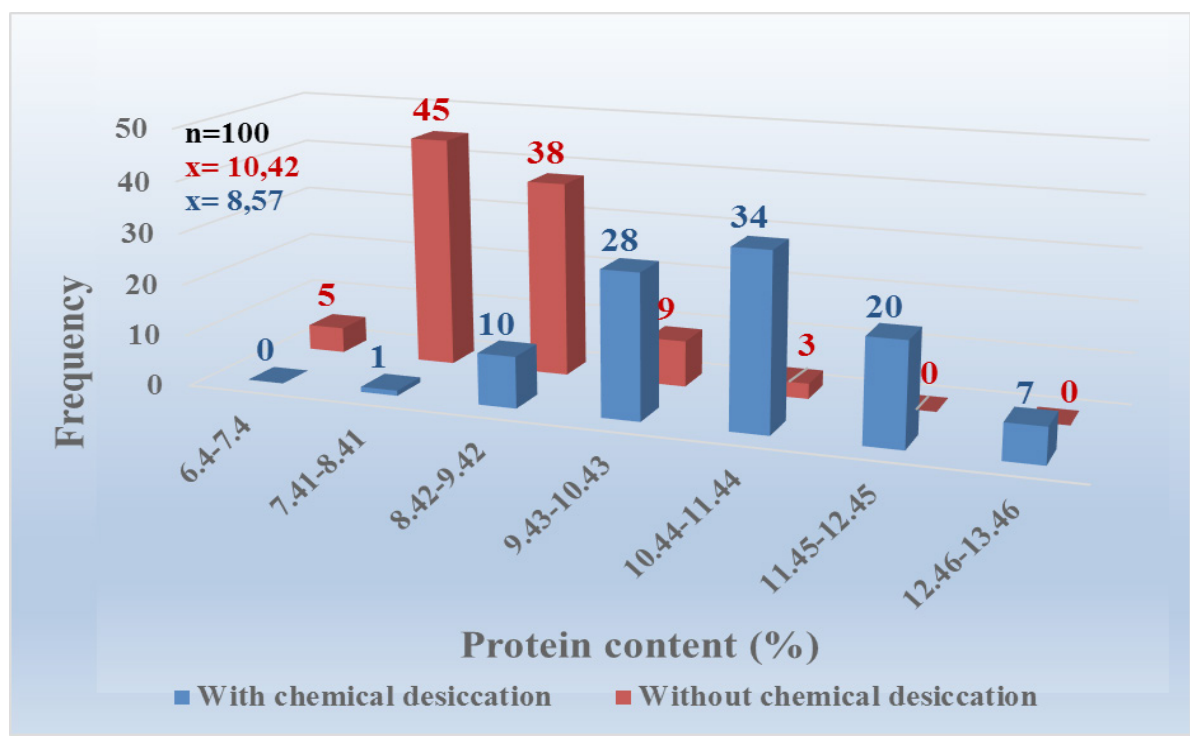

Fig. 3. Distribution of the winter wheat genotypes studied for protein content (Turda, 2014) 
11, T.54-01, T.65-11. The variability parameters for wet gluten content (Table 3) obtained at 100 winter wheat genotypes studied in the year 2014, at A.R.D.S. Turda indicated, as for the protein content, that the average for the genotypes grown in normal coditions (19.49\%) was lower than the average recorded for genotypes under chemical stress $(26,23 \%)$.

In the case of genotypes untreated with $\mathrm{NaClO}_{3}$ the range of variation for wet gluten content was 23.1 percent with limits between 9.9 and $33 \%$. The value of standard deviation (5.41) indicated that the experimental results don't have values around their average.

The wet gluten content for chemical desicated genotypes was between 17.6 and 40.6 percent with a range of variation of 23 . For these ones, standard deviation shows that the wet gluten content, in most analyzed genotypes, have values close to the average.

The coefficient of variation for chemical desicated genotypes (20.62) indicated high variability of statistical repartition while the the coefficient of variation for the genotypes without treatment shows a medium variability of the experimental values.

The distribution of winter wheat genotypes studied for wet gluten content (Fig. 4) shows that in dry conditions, only 12 of the analyzed genotypes have a wet gluten content close to the average with values between $24.95-27.95 \%$ while in normal condition, most of them (43) had wet gluten content between 18.93-21.93\%, close to the average of all 100 genotypes studied.

Among the 10 genotypes with the highest wet gluten content (Table 4) are found varieties but

Tab. 2. Winter wheat genotypes with the highest protein values from the ARDS Turda (Turda,2014)

\begin{tabular}{ccccc}
\hline \multirow{2}{*}{ Rank } & \multicolumn{2}{c}{ Treated with $\mathrm{NaClO}_{3}$} & \multicolumn{2}{c}{ Untreated } \\
\cline { 2 - 5 } & Genotypes & Protein content \%) & Genotypes & Protein content (\%) \\
\hline 1 & GK. Kalasz & 13.7 & Apullum & 11.4 \\
\hline 2 & T 265- 01 & 13.4 & T.265- 01 & 11.4 \\
\hline 3 & Gruia & 13.1 & Capo & 10.8 \\
\hline 4 & Pitar & 13.0 & Aniversar & 10.3 \\
\hline 5 & Apullum & 12.9 & T.126- 11 & 10.0 \\
\hline 6 & Aniversar & 12.4 & T 54- 01 & 9.9 \\
\hline 7 & Bezostaia & 12.4 & T.65- 11 & 9.9 \\
\hline 8 & Josef & 12.0 & Rovine & 9.8 \\
\hline 9 & Serina & 11.9 & Bezostaia & 9.7 \\
\hline 10 & T.23- 12 & 11.9 & GK. Kalasz & 9.5 \\
\hline
\end{tabular}

Tab. 3. Wet gluten content parameters variability for 100 winter wheat genotypes studied at A.R.D.S. Turda in the year 2014

\begin{tabular}{|c|c|c|}
\hline & \multicolumn{2}{|c|}{ Ash content (\%) (Turda, 2014) } \\
\hline & Treated & Untreated \\
\hline Statistical population & 100 genotypes & 100 genotypes \\
\hline Mean & 26.23 & 19.49 \\
\hline Standard deviation & 5.41 & 3.85 \\
\hline Skewness & 0.32 & 0.63 \\
\hline Range of variation & 23 & 23.1 \\
\hline \multirow{3}{*}{$\begin{array}{l}\text { nge of variation } \frac{\text { Minimum }}{\text { Maximum }} \\
\text { Coefficient of variation }(\mathrm{s} \%)\end{array}$} & 17.6 & 9.9 \\
\hline & 40.6 & 33 \\
\hline & 20.62 & 19.75 \\
\hline
\end{tabular}


also perspective lines of winter wheat genotypes Apullum, Rovine, Bezostaia, Glosa, Josef and Gk. Kalasz have high content of wet gluten when are grown in normal conditions. After chemical desiccation, Gk. Kalasz has the highest value for wet gluten content (40.6).

In dry conditions, all 10 genotypes presented in the Table 4 have values of wet gluten content highest than 33\%.Based on the ash content of flours can be achieved classification according to quality classes.

Considering the ash content of the 100 analyzed genotypes we observed that average of desicated genotypes is $1.70 \%$ and the range of variation is $2.08 \%$ with values between $0.42 \%$ and 2.5. Standard deviation (0.45) indicating that the experimental values are far from the average for ash content.

The coefficient of variation (26.47) shows a large variability of the statistical repartitions. In the case of untreated genotypes we can observe a smaler medium value for ash content, with $0.52 \%$, than in the treated genotypes.

The range of variation for 100 winter wheat genotypes is 2.31 with values between 0.22 and

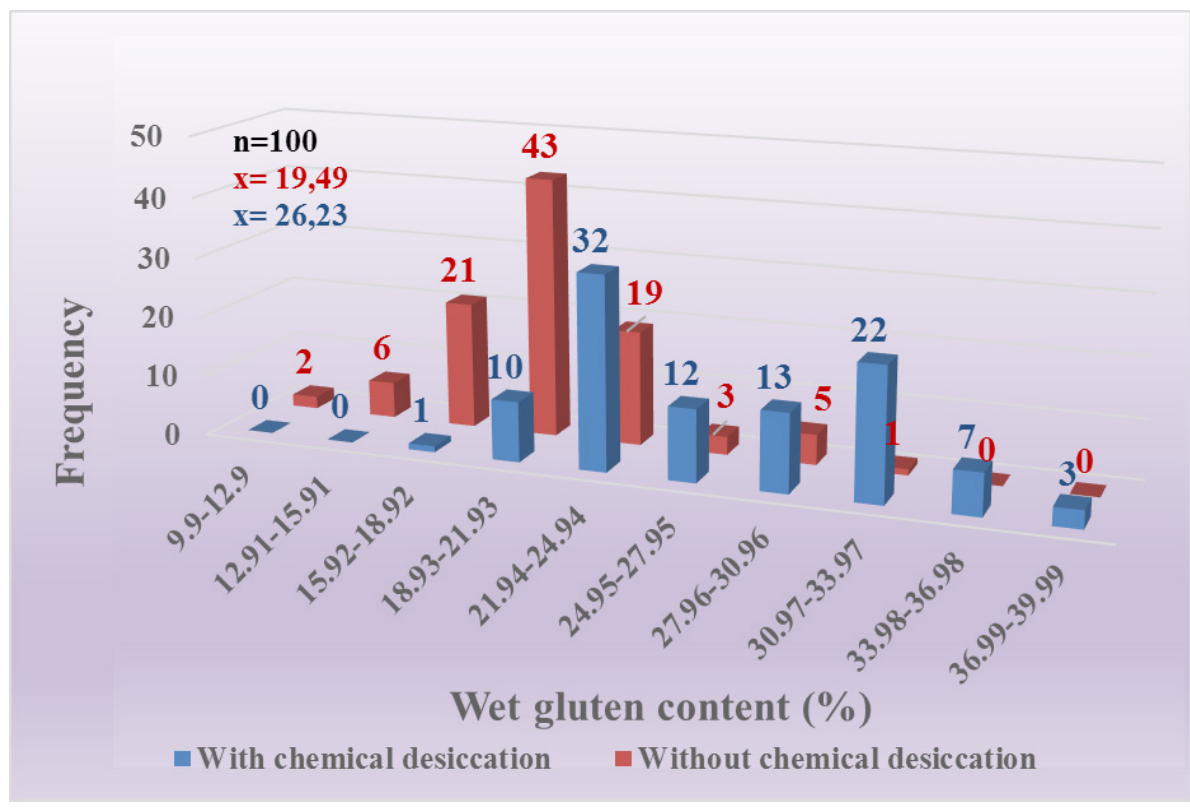

Fig. 4. Distribution of the winter wheat genotypes studied for wet gluten content (Turda, 2014)

Tab. 4. Winter wheat genotypes with the highest protein values from the ARDS Turda (Turda,2014)

\begin{tabular}{ccccc}
\hline \multirow{2}{*}{ Rank } & \multicolumn{2}{c}{ Treated with $\mathrm{NaClO}_{3}$} & \multicolumn{2}{c}{ Untreated } \\
\cline { 2 - 5 } & Genotypes & Protein content \%) & Genotypes & Protein content (\%) \\
\hline 1 & GK. Kalasz & 40.6 & Apullum & 33 \\
\hline 2 & Apullum & 37.2 & T.265- 01 & 29.4 \\
\hline 3 & Pitar & 36.8 & Rovine & 28.7 \\
\hline 4 & T.265- 01 & 35.9 & Capo & 28.5 \\
\hline 5 & Gruia & 35.4 & T.126- 11 & 26.4 \\
\hline 6 & Delabrad & 35.2 & Bezostaia & 26.2 \\
\hline 7 & Josef & 34.8 & Glosa & 25.4 \\
\hline 8 & Exotic & 34.1 & T.124- 11 & 24.6 \\
\hline 9 & Glosa & 33.9 & Josef & 24.5 \\
\hline 10 & Pratener & 33.8 & GK. Kalasz & 23.6 \\
\hline
\end{tabular}


2.53. The coefficient of variation (33.05) shows a very large variability of statistical statistical data.

The distribution of winter wheat genotypes studied for ash content (Fig. 5) reveals that that most of the untreated genotypes have an ash content between $1.27-1.47 \%$ and the majority of genotypes with chemical desiccation have values for ash content between 1.90-2.10\%. First 10 genotypes with highest ash content (Tab. 5) shows that desiccated genotypes have higher values for ash content than genotypes grown in normal conditions.
In the table below (Tab. 6) are found productions achieved for 10 of genotypes identified as terms of quality superior in the year 2014. The highest yield was achieved by Glosa variety with $10,660 \mathrm{~kg} / \mathrm{ha}$, with a rate of reduction after desiccation of 32.05 .

Bezostaia variety used as check in terms of quality had the lowest production for untreated variant $(6,615 \mathrm{~kg} / \mathrm{ha})$. It was affected by chemical stress caused after flowering achieving, in this case, production of $2,860 \mathrm{~kg} / \mathrm{ha}$ with a rate of reduction of $56.77 \%$.

Tab. 5. Ash content parameters variability for 100 winter wheat genotypes studied at A.R.D.S. Turda in the year 2014

\begin{tabular}{|c|c|c|}
\hline & \multicolumn{2}{|c|}{ Ash content (\%) (Turda, 2014) } \\
\hline & Treated & Untreated \\
\hline Statistical population & 100 genotypes & 100 genotypes \\
\hline Mean & 1.70 & 1.18 \\
\hline Standard deviation & 0.45 & 0.39 \\
\hline Skewness & -0.70 & 0.47 \\
\hline Range of variation & 2.08 & 2.31 \\
\hline \multirow{2}{*}{ Range of variation- } & 0.42 & 0.22 \\
\hline & 2.5 & 2.53 \\
\hline Coefficient of variation (s\%) & 26.47 & 33.05 \\
\hline
\end{tabular}

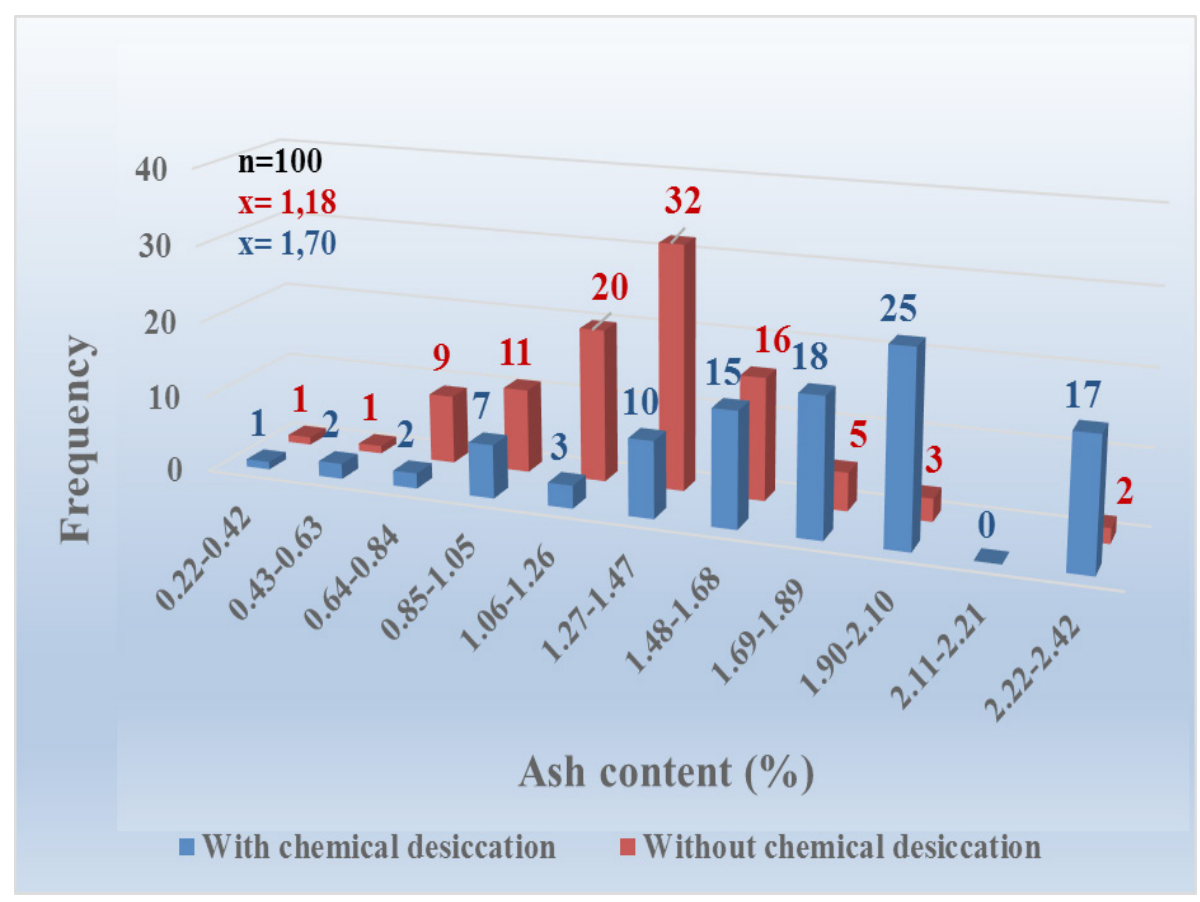

Fig. 5. Distribution of the winter wheat genotypes studied for ash content (Turda, 2014) 
Tab. 5. Winter wheat genotypes with the highest ash values from the ARDS Turda (Turda,2014)

\begin{tabular}{ccccc}
\hline \multirow{2}{*}{ Rank } & \multicolumn{2}{c}{ Treated with $\mathrm{NaClO}_{3}$} & \multicolumn{2}{c}{ Untreated } \\
\cline { 2 - 5 } & Genotypes & Protein content \%) & Genotypes & Protein content (\%) \\
\hline 1 & T 265- 01 & 2.5 & Capo & 2.53 \\
\hline 2 & Josef & 2.48 & T 265- 01 & 2.46 \\
\hline 3 & Pitar & 2.46 & Apullum & 2 \\
\hline 4 & Bezostaia & 2.41 & Josef & 1.92 \\
\hline 5 & GK. Kalasz & 2.39 & Rovine & 1.92 \\
\hline 6 & T.23- 12 & 2.36 & Element & 1.83 \\
\hline 7 & Delabrad & 2.31 & Bezostaia & 1.74 \\
\hline 8 & Gruia & 2.29 & T.126- 11 & 1.7 \\
\hline 9 & Kolo & 2.23 & GK. Kalasz & 1.65 \\
\hline 10 & T. 208- 11 & 2.19 & Turda 95 & 1.62 \\
\hline
\end{tabular}

Tab. 6. Production for 10 winter wheat varieties studied at A.R.D.S. Turda (Turda 2014)

\begin{tabular}{ccccc}
\hline Rank & Genotypes & $\begin{array}{c}\text { Production for untreated } \\
\text { genotypes }(\mathrm{kg} / \mathrm{ha})\end{array}$ & $\begin{array}{c}\text { Production for desicated } \\
\text { genotypes }(\mathrm{kg} / \mathrm{ha})\end{array}$ & $\begin{array}{c}\text { Rate of reduction } \\
(\%)\end{array}$ \\
\hline 1 & Glosa & 10,660 & 7,243 & 32.05 \\
\hline 2 & Josef & 10,110 & 4,396 & 56.52 \\
\hline 3 & Pitar & 9,912 & 6,326 & 36.18 \\
\hline 4 & Gruia & 9,695 & 6,638 & 31.53 \\
\hline 5 & Flamura 85 & 9,544 & 5,744 & 39.82 \\
\hline 6 & Rovine & 9,502 & 6,429 & 32.34 \\
\hline 7 & GK. Kalasz & 9,443 & 6,736 & 28.67 \\
\hline 8 & Apullum & 9,011 & 5,381 & 40.28 \\
\hline 9 & Aniversar & 7,612 & 3,660 & 51.92 \\
\hline 10 & Bezostaia & 6,615 & 2,860 & 56.77 \\
\hline
\end{tabular}

\section{CONCLUSIONS}

Genotypes desiccation, 2 weeks after flowering, has affected both in terms of quality and in terms of production.

Apullum and Aniversar varieties had a protein content higher than $10 \%$ in normal conditions and over $12 \%$ in dry conditions. We also recomand for breeding programs in terms of protein content to use as genitors varieties like Capo, Rovine, GK. Kalasz, Bezostaia but also lines like: T.265-01. T.126-11, T.54-01, T.65-11.

Apullum, Rovine, Bezostaia, Glosa, Josef and Gk. Kalasz have high content of wet gluten when are grown in normal conditions. After chemical desiccation, Gk. Kalasz has the highest value for wet gluten content (40.6). In dry conditions, all 10 genotypes presented in the Table 4 have values of wet gluten content highest than 33\%.
First 10 genotypes with highest ash content shows that desiccated genotypes have higher values for ash content than genotypes grown in normal conditions.

The highest yield was achieved by Glosa variety with $10,660 \mathrm{~kg} / \mathrm{ha}$, with a rate of reduction after desiccation of 32.05 . Bezostaia variety used as check in terms of quality had the lowest production for untreated variant $(6,615 \mathrm{~kg} / \mathrm{ha})$. It was affected by chemical stress caused after flowering achieving, in this case, production of $2,860 \mathrm{~kg} / \mathrm{ha}$ with a rate of reduction of 56.77 percent.

Aknowledgements. This paper was published under the frame of European Social Fund, Human Resources Development Operational Programme 2007-2013, project no. POSDRU/159/1.5/S/ 132765 . 


\section{REFERENCES}

1. Cseuz L, Pauk J, Kertész Z, Matuz J, Fónad P, Tari I,. Erdei $\mathrm{L}$ (2002). Wheat breeding for tolerance to drought stress at the Cereal Research Non-Profit Company in: Acta Biologica Szegediensis, 46: 3-4, 25-26.

2. Hruskova M, Hanzlikova K., Varacek R. (2000). Wheat and flour quality relations in a commercial mill, Czech J. Food Sci., 19: 189-195.

3. Hussain I., Khan MA, Khan EA (2006). Bread wheat varieties as influenced by different nitrogen levels, J. Zhejiang Univ.Sci, 7 (1): 70-78.
4. Marque V, Fritz AK, Martin TJ, Paulsen GM (2004). Agronomic and quality attributes of winter durum wheat in the Central Great Plains, Crop Sci., 44: 878-883.

5. Vogel KP, Johnson VA, Mattern PJ (1973). Results of systematic analyses for protein and lysine composition of common wheats (Triticum aestivum L.) in the USDA world collection. Res. Bul., 258: 1-26.

6. ***http://www.rompan.ro/grau/ 